\title{
GENERACIÓN DE BIOMASA Y RENDIMIENTO EN TRIGO FRENTE A INFECCIONES DE PUCCINIA TRITICINA Y PYRENOPHORA TRITICI-REPENTIS
}

\author{
SchierenbeCK, M. ${ }^{1,2}$; Fleitas, M.C. ${ }^{1,2} ;$ GoliK, S. I. ${ }^{1} \&$ Simón M.R. ${ }^{1}$
}

\begin{abstract}
RESUMEN
El objetivo del presente trabajo fue evaluar el efecto de un patógeno fúngico biotrófico (Puccinia triticina), causal de la roya de la hoja (RH) y un necrotrófico (Pyrenophora tritici-repentis), causal de la mancha amarilla (MA) sobre los atributos fisiológicos vinculados a la generación de biomasa y rendimiento en trigo. Se condujo un ensayo durante 2012 y 2013 utilizando un diseño experimental en parcela sub-dividida con tres repeticiones. Las parcelas principales fueron las inoculaciones con los patógenos. Las sub-parcelas fueron: 1-Sin inóculo y aplicación de fungicida, 2-baja concentración de inóculo y 3-alta concentración de inóculo. Como sub-sub-parcela se sembraron 10 cultivares de trigo. Los resultados indican que MA afectó más la absorción de radiación a partir de mayores niveles de senescencia foliar, en tanto que RH afectó más la eficiencia en el uso de la radiación, probablemente por la interacción particular que los patógenos biotróficos presentan con las células del hospedante.

Palabras Claves: Biomasa; Radiación absorbida; Eficiencia de uso de la radiación; Patógenos foliares; Trigo.
\end{abstract}

\begin{abstract}
Wheat biomass and yield generation under Puccinia triticina and Pyrenophora tritici-repentis infections.

The present study was designed to determine the effects of inoculations of foliar disease pathogens with different nutritional habits: Pyrenophora tritici-repentis (necrothroph -PTR-) and Puccinia triticina (biotroph -LR-) on the physiological components of biomass generation, like absorbed photosynthetic active radiation (APAR) and radiation use efficiency (RUE), and on the
\end{abstract}

1.- Cátedra de Cerealicultura. Facultad de Ciencias Agrarias y Forestales, UNLP. Av. 60 y 119 s/n. La Plata, Buenos Aires, Argentina (CP: 1900). Tel.: +54 (0221) 423-6758. Email: Email: m_schierenbeck@hotmail.com 2.- CONICET CCT La Plata. Calle 8 Nº 1467. La Plata, Buenos Aires, Argentina. Tel.: +54 (0221) 457-6423. Manuscrito recibido el 27 de julio de 2015 y aceptado para su publicación el 11 de noviembre de 2015. 
M. Schierenbeck et al.

yield production in wheat. Field experiments were carried out in 2012-2013 at FCAyF-UNLP using a split-split-plot design with three replications. The main plots were the pathogen inoculations. Subplots were inoculation treatments: 1-Without inoculation, 2-Low dose of spores concentration inoculation, 3 - High dose of spores concentration. Ten cultivars were the sub-subplots. Foliar diseases decreased biomass production mainly explained by reductions in green leaf area, healthy area duration and reductions on APAR, showing higher declines under PTR inoculations. A detrimental effect in the RUE was detected at LR inoculations, which could be associated with the nutritional habit of the pathogen. Key Words: Biomass; Radiation use efficiency; Radiation absorption; Foliar diseases; Wheat

\section{INTRODUCCIÓN}

Las enfermedades foliares constituyen uno de los principales factores bióticos que limitan la expresión de los rendimientos y calidad del cultivo de trigo en todo el mundo (11). En Argentina, se considera que las de mayor importancia relativa son aquellas enfermedades fúngicas que afectan tejidos foliares como la roya de la hoja (agente causal Puccinia triticina Eriks) y la mancha amarilla [Pyrenophora tritici-repentis (Died.) Drechs., anamorfo Drechslera tritici-repentis) (Died.) Shoem. ] La mancha amarilla (MA) es causada por un patógeno necrotrófico por lo que obtiene los nutrientes necesarios para su crecimiento de tejido muertos, luego de matar al hospedante por secreción de toxinas que generan la degradación de las paredes celulares y produciendo consecuentemente las características lesiones cloróticas y necróticas (10). Por otro lado, la roya de la hoja $(\mathrm{RH})$ es causada por un patógeno biotrófico que obtiene los nutrientes exclusivamente de tejidos vivos y utiliza estos recursos para su crecimiento y esporulación (19), caracterizándose por producir profundos cambios en la fisiología de los hospedantes, ya que alteran el metabolismo de las plantas al parasitar las células vivas.

La producción de biomasa para un am- plio rango de cultivos como el trigo (Triticum aestivum L.) depende de la capacidad del canopeo de (i) interceptar la radiación incidente (eficiencia de intercepción, Ei), que es función del índice de área foliar (IAF) y la arquitectura del canopeo (coeficiente de extinción k) y (ii) la eficiencia con que se convierte la energía lumínica en biomasa (eficiencia en el uso de la radiación, EUR). Diversos autores afirman que las enfermedades afectan principalmente la Ei, principalmente por reducciones del área verde y aumentos de la intercepción de radiación por área foliar enferma que no podrá ser utilizada para la generación de biomasa (5). El efecto de las enfermedades sobre la EUR presenta resultados contradictorios en la bibliografía: sin embargo, algunos trabajos indican que enfermedades originadas por patógenos biotróficos podrían disminuir la EUR (13).

El grado de daño que producirá una determinada enfermedad dependerá no sólo de la incidencia y/o severidad del patógeno, sino también del impacto sobre los atributos del cultivo responsables de la asimilación de carbono en el sistema (20). En ese sentido, algunos autores sostienen que el estudio del impacto de los patógenos sobre variables relacionadas a la ecofisiología del cultivo como el IAF verde (IAFV), duración del área foliar verde (DAFV) y sobre 